\section{Immunoproteomics and immunoinformatics analysis of Cryptococcus gattii: novel candidate antigens for diagnosis}

Liline Maria Soares Martins ${ }^{\star 1,2}$, Hélida Monteiro de Andrade ${ }^{3}$, Marilene Henning Vainstein ${ }^{4}$, Bodo Wanke ${ }^{5}$, Augusto Schrank ${ }^{4}$, Claudia Bemfica Balaguez ${ }^{4}$, Patrícia Ribeiro dos Santos ${ }^{4}$, Lucélia Santi ${ }^{4}$, Simone da Fonseca Pires ${ }^{3}$, Adalberto Socorro da Silva', José Adail Fonseca de Castrol,2, Rafael Melo Santos de Serpa Brandão' \& Semiramis Jamil Hadad do Monte'

\begin{abstract}
"Laboratório de Imunogenética e Biologia Molecular, Universidade Federal do Piauí, Campus Ministro Petrônio Portella Bloco SG-16, 64049-550, Teresina, Piauí, Brazil

2Faculdade de Ciências Médicas da Universidade Estadual do Piauí, Teresina, Piauí, Brazil 3Universidade Federal de Minas Gerais, Instituto de Ciências Biológicas, Departamento de Parasitologia Belo Horizonte, Minas Gerais, Brazil

${ }^{4}$ Centro de Biotecnologia, Universidade Federal do Rio Grande do Sul, Porto Alegre, Rio Grande do Sul, Brazil 5Laboratório de Micologia, Instituto de Pesquisa Clínica Evandro Chagas-Fiocruz, Rio de Janeiro, Brazil *Author for correspondence: liline-martins@uol.com.br
\end{abstract}

Aim: To identify immunoreactive proteins of Cryptococcus gattii genotype VGII and their B-cell epitopes. Materials \& methods: We combined 2D gel electrophoresis, immunoblotting and mass spectrometry to identify immunoreactive proteins from four strains of C. gattii genotype VGII (CG01, CG02, CG03 and R265). Next, we screened the identified proteins to map B-cell epitopes. Results: Sixty-eight immunoreactive proteins were identified. The strains and the number of proteins we found were: CG01 (12), CG02 (12), CG03 (18) and R265 (26). In addition, we mapped 374 peptides potentially targeted by B cells. Conclusion: Both immunoreactive proteins and B-cell epitopes of $C$. gattii genotype VGIl that were potentially targeted by a host humoral response were identified. Considering the evolutionary relevance of the identified proteins, we may speculate that they could be used as the initial targets for recombinant protein and peptide synthesis aimed at the development of immunodiagnostic tools for cryptococcosis.

Cryptococcosis has become a significant public global health problem. The CDC estimate the occurrence of over 1 million new cases per year of cryptococcosis worldwide in patients with AIDS and, despite the recent improvements in the diagnosis and treatment of cryptococcosis, cryptococcal meningitis is responsible for over 600,000 deaths per year worldwide. This potentially fatal fungal disease is caused by one of two species of the same genus: Cryptococcus neoformans (genotypes VNI-VNIV) or Cryptococcus gattii (genotypes VGI-VGIV). The first species is best known as the cause of severe meningoencephalitis or meningitis in immunocompromised patients and has been considered to be the most medically important species for many years [1-5]. It is important for clinical microbiology laboratories to accurately differentiate one species from the other. Rapid identification of $C$. neoformans and C. gattii is imperative for favoring the prompt treatment of cryptococcosis and for understanding the epidemiology of the disease [6-11]. C. gattii merits more attention so that its environmental occurrence and role in cryptococcosis can be accurately determined, as this information will be helpful in devising strategies to manage potential outbreaks of cryptococcosis. Today, the differentiation between C. neoformans and C. gattii is a difficult task since: the available commercial differentiation methods (e.g., API ${ }^{\circledR}$ 20C AUX [bioMérieux, France], Vitek ${ }^{\circledR}$ [bioMérieux] and MicroScan ${ }^{\circledR}$ [Siemens, Germany]) do not differentiate between $C$. neoformans and C. gattii; and the methods capable of differentiating the two species (multiplex PCR, liquid array detection of pathogens, PCR restriction fragment length polymorphism $[12,13]$ and matrix-assisted laser desorption/ionization mass spectrometry [MS] [14-16]) are not routinely used.

Recently, however, increased medical attention has been paid to $C$. gattii, which mainly affects immunocompetent individuals $[1,2,17]$. The interest in clinical studies of this species has arisen due to its rapid spread in Asia, Africa, Australia, Europe and South America, along with outbreaks in Vancouver Island, BC, Canada, and in parts
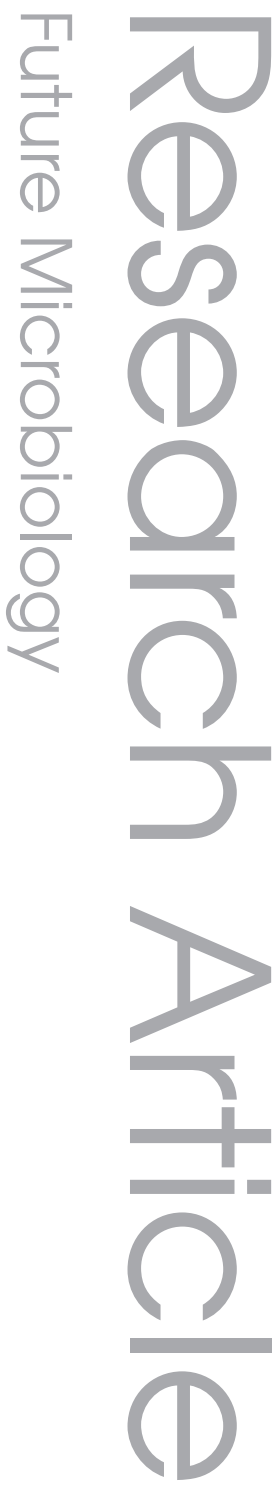

\section{Keywords}

- B cell $=$ cryptococcosis

- Cryptococcus gattii

- diagnosis = epitopes

- immunoinformatics

- immunoproteomics

\section{Future $\because$ Medicine part of}


of continental North America. The potential for C. gattii to cause illness in immunocompetent patients and its rapid spread worldwide justify the implementation of a public health effort to increase the awareness of both the public and healthcare professionals [1,18-24]. The mechanism of $C$. gattii dispersion is not well understood. However, it is thought that the emergence of industrialization, as well as the subsequent development of high population densities, concurrent with processes such as the export of trees and wood products, transport of bacteria via air currents, water currents and biotic agents (e.g., birds, animals and insects) and global warming, may be the main catalysts for the spread of this pathogen $[1,2]$. As cryptococcosis does not require compulsory notification in Brazil, and there is currently no surveillance of this mycosis, its prevalence and annual incidence can only be approximately estimated based on publications of cases occurring in specialized services. Nevertheless, it is well known that the clinical cases attributed to these two species of the Cryptococcus genus are distributed differently throughout Brazil, with $C$. neoformans being predominant in the south and southeast and $C$. gattii (mainly genotype VGII) being predominant in the north and northeast regions. In these latter two regions, C. gattii affects immunocompetent adults, adolescents and children, and is associated with high morbidity and mortality rates (ranging from 37 to 49\%). Information regarding the conditions that support the development of cryptococcosis in immunocompetent individuals remains elusive. However, it is possible that environmental factors play an important role in this process, considering that people living in endemic areas are at high risk for developing the disease [21,25-30]. Preventative measures that effectively combat infection by $C$. gattii are not available at present. Hence, the best approach for controlling cryptococcosis is through early diagnosis and treatment. Although recent advances directed at early diagnosis of cryptococcosis have been published [31-33], a diagnostic method with high specificity and sensitivity to guide the management and control of cryptococcosis remains to be developed.

Information from the recently published C. gattii genome, combined with data obtained via proteomic approaches, has created opportunities for the development of diagnostic tools and therapeutic targets in the context of cryptococcosis caused by $C$. gattii [18]. The development of such tools has been improved by the production of antigens, which increases the range of alternative tests for immunoassay-based pathogen detection. In this study, we identify both immunoreactive proteins of $C$. gattii and predicted B-cell epitopes for their potential use as antigens in new serologic tests.

\section{Materials \& methods \\ Study patients \& sera}

The study included three immunocompetent subjects with cryptococcal meningitis recruited at the Natan Portella Institute of Tropical Diseases, a reference center for infectious diseases in Teresina, the capital of the northeastern state of Piauí, Brazil. As negative controls, we used sample sera from uninfected subjects $(n=3)$ who did not present clinical indicators or positive serological tests for cryptococcosis. The sera obtained from these patients were stored in a freezer at $-20^{\circ} \mathrm{C}$ until use. The demographic, epidemiological, laboratory and baseline clinical characteristics of each patient were obtained from medical records and transferred to an epidemiological sheet. Detailed information regarding the patients involved in this study was published by Martins et al. [26]. Sera from three immunocompetent patients with cryptococcal meningitis caused by $C$. gattii genotype VGII were selected to produce a pool of serum containing each antigen at a titer of 1:1024 as determined by the latex agglutination test for diagnosing cryptococcosis. This pooled serum was used for all western blot experiments.

\section{C. gattii strains}

C. gattii proteins were screened in four different strains. The first strain, R265 (ATCC number: MYA 4093), was previously identified by Kidd et al. [20] and was kindly provided by MH Vainstein from the culture collection of the Laboratory of Fungi of Medical and Biotechnological Importance from the Biotechnology Center, Federal University of Rio Grande do Sul (UFRGS), Brazil. The other three C. gattii strains (CG01, CG02 and CG03) molecular type/genotype VGII involved in this study were isolated from immunocompetent patients who had cryptococcal meningitis (two children and one adult, from the state of Piauí, northeastern Brazil). These isolates were submitted to strain identification [26], which was performed via PCR restriction fragment length polymorphism analysis using URA5 as a target gene, as described by Meyer et al. [34].

\section{Culture conditions}

Strains were recovered from $15 \%$ skimmed milk stocks, stored at $-20^{\circ} \mathrm{C}$ prior to use. The strains 
were maintained on yeast extract-peptone-dextrose (YPD) media (1\% yeast extract, $2 \%$ peptone, $2 \%$ dextrose and $2 \%$ Bacto $^{\mathrm{TM}}$ Agar, Becton Dickinson, NJ, USA). Each isolate was inoculated and grown in $200 \mathrm{ml}$ of YPD broth at $37^{\circ} \mathrm{C}$ for $24 \mathrm{~h}$ with shaking at $200 \mathrm{rpm}$. To obtain a better protein yield, the cultures were subsequently quantified in a Neubauer chamber, reseeded to an equivalent of $4 \times 10^{7}$ cells $/ \mathrm{ml}$ in $200 \mathrm{ml} \mathrm{YPD}$ final broth and incubated under the same conditions as described above. After $24 \mathrm{~h}$, the cells were collected via centrifugation at $7500 \mathrm{~g}$ for $10 \mathrm{~min}$ at $10^{\circ} \mathrm{C}$ and washed three times in cold, sterile Milli- ${ }^{\circledR}$ water (Millipore Corp., MA, USA). The cell pellet obtained was stored at $-80^{\circ} \mathrm{C}$.

\section{Preparation of protein extracts}

Prior to the extraction process, the samples were lyophilized (FreeZone ${ }^{\circledR}$ lyophilizer, Labconco, MI, USA) and macerated in liquid nitrogen until a fine powder was obtained. The samples were suspended in a lysis buffer with protease inhibitors and detergents $(50 \mathrm{mM}$ Tris- $\mathrm{HCl} \mathrm{pH} 7.5$, $1 \mathrm{mM}$ EDTA, $1 \mathrm{mM}$ phenylmethanesulfonyl fluoride, $50 \mu \mathrm{M} \mathrm{N}$-p-tosyl-s-phenylalanine chloromethyl ketone, $5 \mathrm{mM}$ iodoacetamide, $4 \% \mathrm{w} / \mathrm{v}$ 3-[(3-cholamidopropyl)dimethylammonio]1-propanesulfonate hydrate (CHAPS) and $0.25 \% \mathrm{v} / \mathrm{v}$ Triton $\left.^{\mathrm{TM}} \mathrm{X}-100\right)$. The proteins were solubilized by vortexing the suspensions for $5 \mathrm{~min}$ at intervals of $1 \mathrm{~min}$ on ice, followed by centrifugation at $10,000 \mathrm{~g}$ for $20 \mathrm{~min}$ at $8^{\circ} \mathrm{C}$. The supernatants were collected and preserved at $-20^{\circ} \mathrm{C}$. The remaining cell debris was suspended in the same buffer, followed by vortexing for $5 \mathrm{~min}$ with intervals on ice every $1 \mathrm{~min}$. The supernatant was collected after centrifugation, pooled with the first supernatant and stored at $-80^{\circ} \mathrm{C}$. The protein content was determined by the Bradford method [35] using known concentrations of bovine serum albumin as the standard.

\section{D gel electrophoresis}

Samples containing $150 \mu \mathrm{g}$ of protein were precipitated using a $2 \mathrm{D}$ gel electrophoresis (2DE) clean-up kit (GE Healthcare, UK) following the manufacturer's instructions, then solubilized in $150 \mu \mathrm{l}$ of isoelectric focusing (IEF) buffer containing $9 \mathrm{M}$ urea, $4 \%(\mathrm{w} / \mathrm{v})$ CHAPS, $1 \%(\mathrm{w} / \mathrm{v})$ dithiothreitol (DTT) and $0.2 \%(\mathrm{v} / \mathrm{v})$ ampholytes $\mathrm{pH}$ 4-7 (Bio-Rad, CA, USA) with 0.002\% orange G. Next, 7-cm immobilized $\mathrm{pH}$ gradient (IPG) strips (linear gradient, $\mathrm{pH} 4-7$, Bio-Rad) were passively rehydrated for $16-18 \mathrm{~h}$. IEF was performed using the PROTEAN ${ }^{\circledR}$ IEF Cell
System (Bio-Rad) at $20^{\circ} \mathrm{C}$ with the following conditions: $250 \mathrm{~V}$ for $15 \mathrm{~min}, 250-4000 \mathrm{~V}$ for $2 \mathrm{~h}$ and $4000 \mathrm{~V}$ until reaching $10,000 \mathrm{~V} / \mathrm{h}$, with a maximum current of $50 \mu \mathrm{A} /$ strip. Focused IPG strips were equilibrated for $15 \mathrm{~min}$ in equilibration buffer I, containing 30\% (v/v) glycerol, $6 \mathrm{M}$ urea, $1 \%$ DTT, $2 \%$ (w/v) sodium dodecyl sulfate (SDS), $0.375 \mathrm{M}$ Tris $\mathrm{pH} 8.8$ and $0.002 \%$ Bromophenol Blue, and then alkylated for $15 \mathrm{~min}$ in equilibration buffer II (equilibration buffer I in which the DTT was replaced with $4 \%$ iodoacetamide). SDS-PAGE was performed using the method developed by Laemmli [36]. The IPG strips were then placed on a $12 \%$ SDS-PAGE gel, and the second dimension of separation was performed in two steps at $10^{\circ} \mathrm{C}$ : $50 \mathrm{~V} /$ gel for $30 \mathrm{~min}$ and $100 \mathrm{~V} / \mathrm{gel}$ until the tracking dye reached the bottom of the gels in a Mini-PROTEAN Tetra Cell Chamber (BioRad), according to the manufacturer's instructions. The gels were stained with Coomassie Brilliant Blue and scanned with a GS-800 ${ }^{\mathrm{TM}}$ scanner (Bio-Rad). Three technical replicates of classical 2DE western blots for each of the four independent biological samples were performed for each strain. A Coomassie Brilliant Blue G250 gel and the other duplicate gel were transferred onto a polyvinylidene difluoride membrane for subsequent western blot analysis [37].

\section{Western blot: 2DE analysis}

The gels were transferred to polyvinylidene difluoride membranes (Hybond ECL ${ }^{\mathrm{TM}}$, GE Healthcare) at $400 \mathrm{~mA}$ for $1 \mathrm{~h}$ in a transfer buffer (25 mM Tris, $192 \mathrm{mM}$ glycine, 2\% w/v SDS and $20 \% \mathrm{v} / \mathrm{v}$ methanol). The membranes were blocked at $4^{\circ} \mathrm{C}$ overnight with $5 \%(w / v)$ nonfat dry milk in phosphate-buffered saline $\mathrm{pH} 7.4$ with Tween ${ }^{\circledR}-20$ (PBS-T; $10 \mathrm{mM} \mathrm{Na} \mathrm{HPO}_{4}$, $1.7 \mathrm{mM} \mathrm{KH}_{2} \mathrm{PO}_{4}, 137 \mathrm{mM} \mathrm{NaCl}, 2.7 \mathrm{mM} \mathrm{KCl}$, and $0.1 \% \mathrm{v} / \mathrm{v}$ Tween-20, Sigma Aldrich, MO, USA) and washed three times for $10 \mathrm{~min}$. The membranes were then incubated with pools of sera from three patients with cryptococcal meningitis, diluted 1:7500 in blocking buffer for $2 \mathrm{~h}$ at $24^{\circ} \mathrm{C}$. This primary antibody dilution was previously determined based on performing western blotting using a $1 \mathrm{D}$ gel with serum dilutions ranging from 1:2000 to 1:10,000. After washing three times with PBS-T, the blots were incubated with antihuman IgG (GE Healthcare) diluted 1:2000 in blocking buffer for $1 \mathrm{~h}$ at $24^{\circ} \mathrm{C}$. The membranes were washed three times with PBS-T buffer for $15 \mathrm{~min}$ and twice with phosphatebuffered saline for $10 \mathrm{~min}$. Finally, the 2DE blots were processed with the ECL detection 
reagent (GE Healthcare) according to the manufacturer's instructions. Images were prepared using the VersaDoc ${ }^{\mathrm{TM}} 4000 \mathrm{MP}$ imaging system (Bio-Rad). The western blots were evaluated in technical triplicates. The immunoreactivity of each spot, representing a positive signal in the western blot analysis, was identified by matching with the position of the corresponding spot on the gel stained with Coomassie Brilliant Blue. To select spots, the images from membranes and gels containing protein extracts were analyzed using an ImageMaster 2D Platinum 6.0 ${ }^{\circledR}$ (GE Healthcare). In order to identify any nonspecific reactions, we discarded all spots that were also reactive with the pool of sera from negative controls. Only the infected reactive spots sera were manually excised, destained, digested with trypsin and subjected to MS to identify the immunoreactive proteins.

\section{Protein identification by liquid chromatography-electrospray ionization-quadrupole-time of flight tandem MS}

Gel plugs were treated through three washing steps with $100 \mu \mathrm{l}$ of $50 \%$ acetonitrile (ACN) and $50 \mathrm{mM}$ ammonium bicarbonate $\left(\mathrm{NH}_{4} \mathrm{HCO}_{3}\right)$ for $15 \mathrm{~min}$, followed by one washing step with $100 \mu \mathrm{l}$ of ACN. After washing, the gel plugs were dried via vacuum centrifugation (CentriVap ${ }^{\circledR}$ Benchtop Centrifugal Vacuum concentrator, Labconco) and subjected to trypsin digestion for $18-24 \mathrm{~h}$ at $37^{\circ} \mathrm{C}$ using $20 \mu \mathrm{l}$ of $10 \mu \mathrm{g} / \mathrm{ml}$ trypsin (Trypsin Gold, MS grade, Promega, WI, USA) diluted in $25 \mathrm{mM}$ $\mathrm{NH}_{4} \mathrm{HCO}_{3}$. Peptide extraction was performed twice for $15 \mathrm{~min}$ with $100 \mu \mathrm{l}$ of a $100 \%$ ACN and 5\% formic acid solution. Trypsin digests were then concentrated in a SpeedVac ${ }^{\circledR}$ concentrator to approximately $10 \mu \mathrm{l}$ and resuspended in $10 \mu \mathrm{l}$ of $0.1 \%$ trifluoroacetic acid.

The resulting peptides were analyzed by liquid chromatography-electrospray ionization-quadrupole-time of flight tandem mass spectrometry (MS/MS) using a Waters nanoACQUITY UPLC $^{\mathrm{TM}}$ system coupled to a Q-TOF Ultima ${ }^{\mathrm{TM}}$ API mass spectrometer (Waters MS Technologies, UK) at the Unit of Protein Chemistry and Mass Spectrometry (Uniprote-MS, Biotechnology Center, UFRGS, Brazil). The peptides were eluted from the reverse-phase column into the mass spectrometer at a flow rate of $600 \mathrm{nl} / \mathrm{min}$ with a $10-50 \%$ water/ACN $0.1 \%$ formic acid linear gradient over $30 \mathrm{~min}$. The MS survey scan was set to $1 \mathrm{~s}$ (0.1 s interscan delay) and recorded at 200-2000 Da. MS/MS scans were performed from 50 to $2000 \mathrm{~m} / \mathrm{z}$, and the scan and interscan rates were set as for MS. For each survey scan, the three most intense multiplecharged ions over a threshold of eight counts were selected for the MS/MS analysis. The collision energies for peptide fragmentation were set using the charge state recognition files for +2 and +3 peptide ions provided by MassLynx ${ }^{\mathrm{TM}}$ (Waters). The raw MS/MS data were processed using Mascot Distiller 2.2.1 software (Matrix Science, MA, USA) to form peak lists that were exported in the Mascot generic format.

\section{Database searches}

The peak lists for each protein spot were analyzed with the aid of the 'MS/MS Ion Search' engine of Mascot (version 2.1) software [101]. The Mascot search parameters were as follows: oxidation of methionine, modification of cysteine by carbamidomethylation, partial cleavage leaving one internal cleavage site, a peptide tolerance of $0.2 \mathrm{Da}$ and a MS/MS tolerance of $0.1 \mathrm{Da}$. The significance threshold was set at $\mathrm{p}<0.05$, and identification required that each protein contained at least one peptide with an expected $\mathrm{p}$-value $<0.05$. Thus, we compared the calculated molecular mass and isoelectric point values from the identified proteins with the observed values on the $2 \mathrm{DE}$ gel. Additionally, if a protein with a nonsignificant score was part of a horizontal series of spots with the adjacent identical proteins, we included this identification. All amino acid sequences were downloaded as FASTAformat files from the Broad Institute protein database [102]. The Blast2GO tool [103] was used to obtain functional categories of proteins. This tool assigns gene ontology (GO) terms based on the Basic Local Alignment Search Tool (BLAST) definitions. This assignment was accomplished by submitting the FASTA sequences of the identified proteins to the Blast2GO platform and comparing them against the National Center for Biotechnology Information (NCBI) databases [104]. Briefly, Blast2GO used BlastP with the default parameters to identify similar proteins with $\mathrm{GO}$ annotations.

\section{Mapping B-cell epitopes}

To map linear B-cell epitopes in the immunoreactive proteins selected by western blotting, we used two different programs: ABCPred [105], which is based on machine-learning methods that apply a recurrent neural network [38], and BCPreds [106], which is also based on machinelearning methods, but involves methods that apply a support vector machine [39]. Only those 
peptides that were simultaneously identified by the two programs were considered to be putative antigens for the development of immunoassays for cryptococcosis. This approach was based on the work of Faria et al., which showed that the use of the default scores of prediction software programs associated with the overlap predictions of more than one software program can be preferable to the use of a single type of prediction [40].

\section{Results}

2DE proteome profiling of C. gattii strains

Proteins from C. gattii strain R265 and our isolates (CG01, CG02 and CG03) were separated using $2 \mathrm{DE}$ and analyzed for reactivity to the serum by immunoblotting. In fact, the capsule was a major obstacle to obtaining protein. The key points to improve protein recovery were background culture in liquid medium and lyophilization with maceration in liquid nitrogen. After these steps, proteins were obtained by solubilization in a lysis buffer containing $4 \%$ detergent (CHAPS). Protein samples obtained in this manner are mainly cytoplasmatic proteins and a trace quantity of membrane proteins associated to carbohydrates.

A representative image of the protein patterns is shown in Figure 1. Image analysis demonstrated approximately 350 spots for each strain of C. gattii (Figure 1), all of which optimally resolved at $\mathrm{pH} 4-7$, and their molecular weights ranged from 12 to $225 \mathrm{kDa}$.

Only 68 of these spots showed reactivity based on immunoblotting against a pool of sera from cryptococcosis patients. One hypothesis to explain the low number of proteins identified by immunoblotting is that most of the proteins were cytoplasmic, together with the fact that many surface antigens of this fungus are located in capsules and should be represented mainly by carbohydrates.

The distribution of the spots for each strain is as follows: 12 spots from CG01; 12 from CG02; 18 from CG03; and 26 from R265. All of the immunoreactive spots selected for identification with MS were classified according to their biological activity (Table $1 \&$ Supplementary Tabie 1 ) (see online at: www.futuremedicine.com/doi/ suppl/10.2217/FMB.13.22). The data generated by the Blast $2 \mathrm{GO}$ analysis are presented at GO multilevels to illustrate the general functional categories according to biological processes and molecular functions (Supplementary Figures 1 \& 2) [103]. Of the 68 spots corresponding to 48 proteins, $34(70.8 \%)$ were selected from only one strain, and $14(29.2 \%)$ were simultaneously derived from at least two strains; among the latter 14 proteins, six were simultaneously selected from three strains (FIGURE 2).

\section{Prediction of B-cell linear epitopes}

We sought to determine whether the 48 reactive proteins identified in this study shared epitopes that were potentially recognized by patient antibodies. Therefore, we screened these proteins for predictive B-cell epitopes using two different bioinformatics tools. The ABCPred program yielded 4747 peptides, whereas BCPreds yielded 475. By comparing the B-cell epitopes generated by these two different approaches, we were able to identify 374 concordant peptides (the peptide sizes ranged from nine to 14 amino acids) (Supplementary Table 2). We believe that the B-cell prediction was efficient because the majority of the proteins $(41 / 48 ; 85.4 \%)$ presented in a high percentage (greater than 25\%) of the epitopes (Table 2). This percentage of epitopes takes into account the total number of predicted peptides and the total number of amino acids in the mapped protein. Two hypothetical proteins (CNBG_1302 and CNBG_1079) contained the highest number of predicted peptides. Proteins and peptides with a greater potential of being B-cell epitopes deserve further investigation as candidate antigens for use in diagnostic testing.

\section{Discussion}

In this immunoproteomic study, we identified immunoreactive proteins in C. gattii, as well as the putative B-cell epitopes of these predicted proteins using immunoinformatics tools. The proteins recognized in vitro by antibodies in this work probably have the same antigenic determinants that induce antibodies in vivo. This approach has frequently been used to identify immunogenic proteins and, consequently, new targets to diagnose several diseases [41-54]. Although similar results have been achieved in cryptococcosis using murine [55] and koala models [56], this is the first report in human beings. In addition, the use of sample isolates obtained directly from patients would be very difficult, because they are hard to obtain directly from the brain or lung during infection, and the sample collected would probably not have a sufficient amount of protein for a proteomic approach.

We identified 68 immunoreactive proteins and highlight that only six of them were reactive in three isolates simultaneously without a reaction for negative sera. Due to their 


\section{Research Article Martins, Andrade, Vainstein et al.}

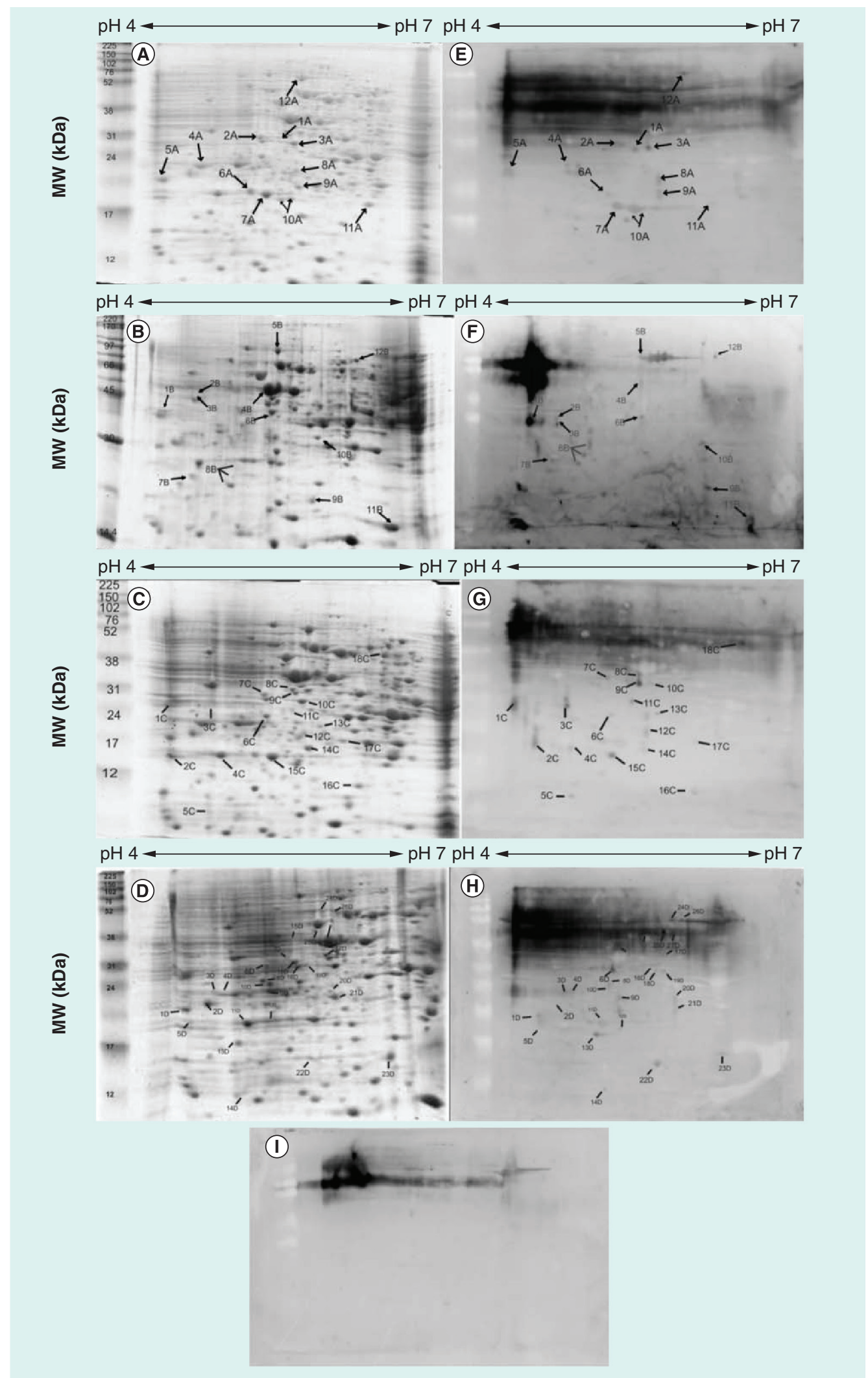

Figure 1. Western immunoblot analysis of representative serum samples. Cryptococcus gatti proteins in 2D gel electrophoresis: (A) CGOI, (B) CGO2, (C) CGO3 and (D) R265. Representative results of immunoblot from the pool of patient sera with cryptococcosis: (E) CGO1, (F) CGO2, (G) CGO3 and (H) R265 strains. (I) Result of immunoblot from the sera of uninfected person with cryptococcosis. The numbers refer to the spot identification used in TABLE $\mathbf{1}$. MW: Molecular weight. 
Table 1. Immunodominant proteins identified by serologic proteome analysis.

\begin{tabular}{|c|c|c|c|c|c|}
\hline Spot/strain & Protein & Accession code & Mascot ID & Biological process & Molecular function \\
\hline $11 \mathrm{~A} / \mathrm{CG} 01$ & Microtubule motor & E6ROY5 & CNBG_0115 & $\begin{array}{l}\text { Microtubule-based } \\
\text { movement }\end{array}$ & $\begin{array}{l}\text { ATP binding; microtubule motor } \\
\text { activity }\end{array}$ \\
\hline 25D/R265 & Heat shock protein sks2 & E6R0K8 & CNBG_0239 & Response to stress & ATP binding \\
\hline 21D/R265 & $\begin{array}{l}\text { HHE domain-containing } \\
\text { protein }\end{array}$ & E6R0I8 & CNBG_0257 & Unknown & Unknown \\
\hline 11C/CG03 & Cytoplasm protein & E6R0G3 & CNBG_0282 & Unknown & Binding \\
\hline $5 \mathrm{~A} / \mathrm{CG} 01$ & $\begin{array}{l}\text { Conserved hypothetical } \\
\text { protein }\end{array}$ & E6R0CO & CNBG_0290 & Unknown & Unknown \\
\hline 7C/CG03 & $\begin{array}{l}\text { Conserved hypothetical } \\
\text { protein }\end{array}$ & E6R068 & CNBG_0372 & Unknown & RNA binding \\
\hline 3D/R265 & $\begin{array}{l}\text { Ubiquitin carboxyl- } \\
\text { terminal hydrolase }\end{array}$ & E6R058 & CNBG_0379 & $\begin{array}{l}\text { Ubiquitin-dependent } \\
\text { protein catabolic process }\end{array}$ & Ubiquitin thiolesterase activity \\
\hline 17D/R265 & Disulfide-isomerase & E6QZV4 & CNBG_0482 & Cell redox homeostasis & $\begin{array}{l}\text { Electron carrier activity; isomerase } \\
\text { activity; protein disulfide } \\
\text { oxidoreductase activity }\end{array}$ \\
\hline 9B/CG02 & $\begin{array}{l}\text { Conserved hypothetical } \\
\text { protein }\end{array}$ & E6R3U6 & CNBG_0624 & Unknown & Unknown \\
\hline 12B/CG02 & Aconitase & E6R432 & CNBG_0705 & Tricarboxylic acid cycle & $\begin{array}{l}\text { Four-iron, four-sulfur cluster binding; } \\
\text { aconitate hydratase activity }\end{array}$ \\
\hline 22D/R265 & Cytoplasm protein & E6R4T7 & CNBG_0959 & Unknown & Unknown \\
\hline 8D/R265 & $\begin{array}{l}\text { Conserved hypothetical } \\
\text { protein }\end{array}$ & E6R568 & CNBG_1079 & Unknown & Unknown \\
\hline 6B/CG02 & $\begin{array}{l}\text { Succinyl-CoA ligase } \\
\beta \text {-chain }\end{array}$ & E6QYKO & CNBG_1185 & Tricarboxylic acid cycle & $\begin{array}{l}\text { ATP binding; succinate-CoA ligase } \\
\text { (ADP-forming) activity }\end{array}$ \\
\hline 9C/CG03 & $\begin{array}{l}\text { Succinyl-CoA ligase } \\
\beta \text {-chain }\end{array}$ & E6QYKO & CNBG_1185 & $\begin{array}{l}\text { Reductive tricarboxylic } \\
\text { acid cycle }\end{array}$ & ATP binding \\
\hline 18D/R265 & $\begin{array}{l}\text { Succinyl-CoA ligase } \\
\beta \text {-chain }\end{array}$ & E6QYKO & CNBG_1185 & Tricarboxylic acid cycle & ATP binding \\
\hline 12C/CG03 & $\begin{array}{l}\text { Conserved hypothetical } \\
\text { protein }\end{array}$ & E6QY79 & CNBG_1302 & Unknown & Unknown \\
\hline 3B/CG02 & Endopeptidase & E6QY25 & CNBG_1355 & Proteolysis & Aspartic-type endopeptidase activity \\
\hline $8 C / C G 03$ & $\begin{array}{l}\text { 3-isopropylmalate } \\
\text { dehydrogenase }\end{array}$ & E6QXQ4 & CNBG_1460 & Oxidation reduction & NAD or NADH binding \\
\hline 16D/R265 & $\begin{array}{l}\text { 3-isopropylmalate } \\
\text { dehydrogenase }\end{array}$ & E6QXQ4 & CNBG_1460 & Oxidation reduction & $\begin{array}{l}\text { 3-isopropylmalate dehydrogenase } \\
\text { activity; NAD binding }\end{array}$ \\
\hline 4B/CG02 & ATP synthase $\beta$-subunit & E6R8N5 & CNBG_1632 & $\begin{array}{l}\text { ATP hydrolysis-coupled } \\
\text { proton transport }\end{array}$ & $\begin{array}{l}\text { ATP binding; hydrogen ion- } \\
\text { transporting ATP synthase activity }\end{array}$ \\
\hline 15D/R265 & ATP synthase $\beta$-subunit & E6R8N5 & CNBG_1632 & ATP catabolic process & $\begin{array}{l}\text { Proton-transporting ATPase activity, } \\
\text { rotational mechanism }\end{array}$ \\
\hline 6D/R265 & $\begin{array}{l}\text { Ketol-acid } \\
\text { reductoisomerase }\end{array}$ & E6R847 & CNBG_1816 & Oxidation reduction & $\begin{array}{l}\text { Coenzyme binding; isomerase } \\
\text { activity; ketol-acid reductoisomerase } \\
\text { activity }\end{array}$ \\
\hline 1C/CG03 & $\begin{array}{l}\text { Glyceraldehyde-3- } \\
\text { phosphate } \\
\text { dehydrogenase }\end{array}$ & E6R7Z5 & CNBG_1866 & Glycolysis & $\begin{array}{l}\text { NAD binding; glyceraldehyde-3- } \\
\text { phosphate dehydrogenase (NAD+) } \\
\text { phosphorylating activity }\end{array}$ \\
\hline 1B/CG02 & $\begin{array}{l}\text { Mannitol-1-phosphate } \\
\text { dehydrogenase }\end{array}$ & E6RA07 & CNBG_2079 & Oxidation reduction & $\begin{array}{l}\text { Oxidoreductase activity; zinc ion } \\
\text { binding }\end{array}$ \\
\hline
\end{tabular}



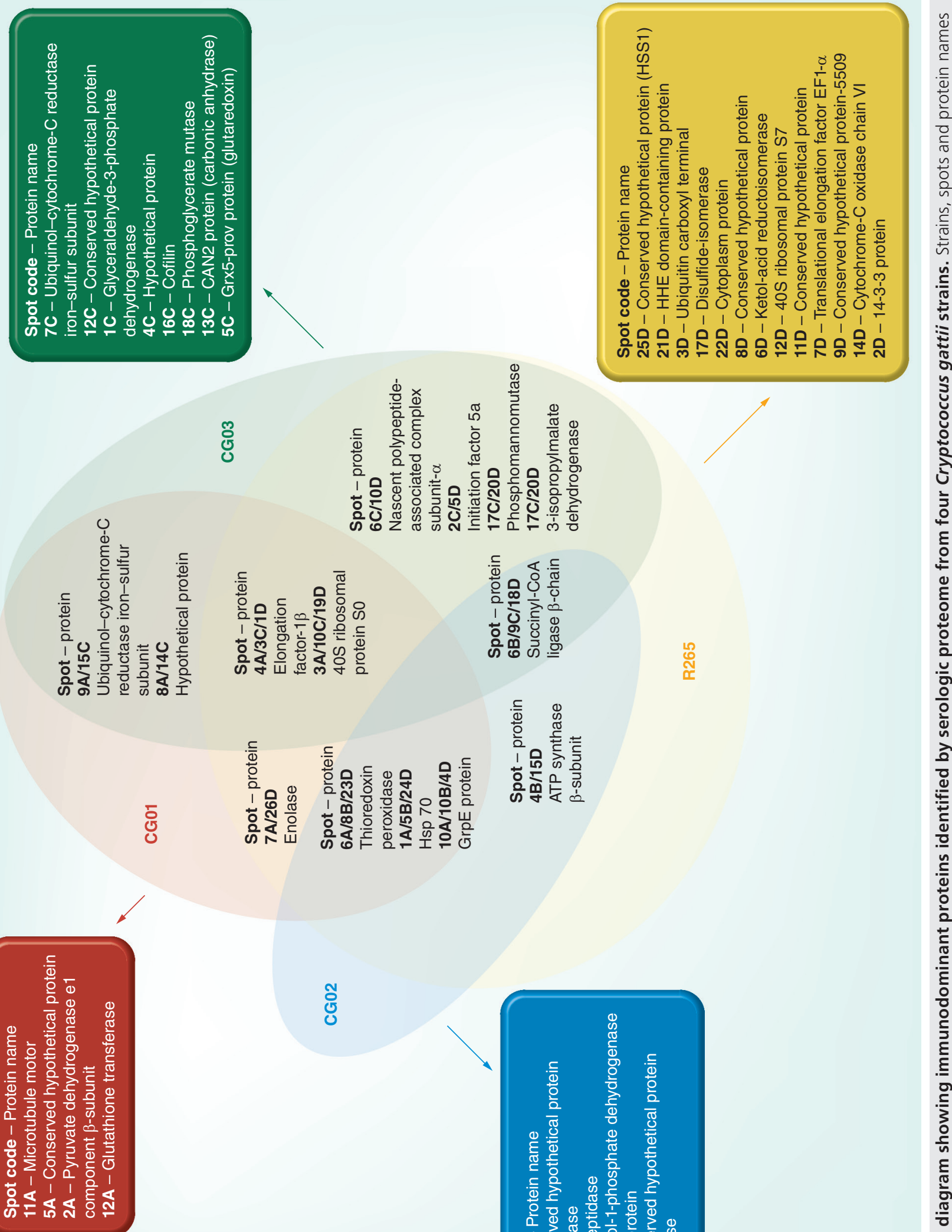

ชั

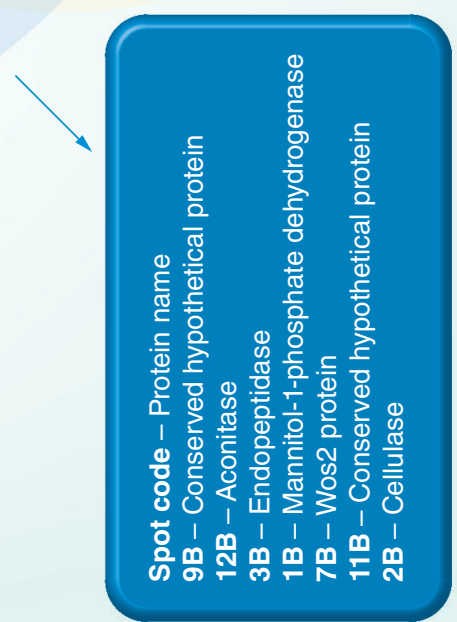


Table 2. Proteins and B-cell epitopes mapped by ABCPred and BCPreds algorithms identified by immunoblot sera from patients with cryptococcosis.

\begin{tabular}{|c|c|c|c|c|c|}
\hline Protein ID (aa+) & Accession code & Name of protein & WB strain ${ }^{ \pm}$ & Epitopes (n) & Epitopes (\%) \\
\hline $\begin{array}{l}\text { CNBG_1302§ } \\
(222)\end{array}$ & E6QY79 & $\begin{array}{l}\text { Conserved hypothetical } \\
\text { protein }\end{array}$ & CG03 & 9 & 47 \\
\hline $\begin{array}{l}\text { CNBG_10795 } \\
(302)\end{array}$ & E6R568 & $\begin{array}{l}\text { Conserved hypothetical } \\
\text { protein }\end{array}$ & R265 & 11 & 42 \\
\hline $\begin{array}{l}\text { CNBG_3163 } \\
(225)\end{array}$ & E6RDR5 & Wos2 protein & CG02 & 8 & 41 \\
\hline $\begin{array}{l}\text { CNBG_0115 } \\
(595)\end{array}$ & E6ROY5 & Microtubule motor & CG01 & 21 & 40 \\
\hline $\begin{array}{l}\text { CNBG_2923 } \\
(292)\end{array}$ & E6RBG9 & $40 S$ ribosomal protein So & $\begin{array}{l}\text { CG01, CG03, } \\
\text { R265 }\end{array}$ & 9 & 35 \\
\hline $\begin{array}{l}\text { CNBG_0705 } \\
(780)\end{array}$ & E6R432 & Aconitase & CG02 & 23 & 34 \\
\hline $\begin{array}{l}\text { CNBG_0282 } \\
(334)\end{array}$ & E6R0G3 & Cytoplasm protein & CG03 & 10 & 34 \\
\hline $\begin{array}{l}\text { CNBG_4548 } \\
(239)\end{array}$ & E6R5R6 & CAN2 protein & CG03 & 7 & 34 \\
\hline $\begin{array}{l}\text { CNBG_4834 } \\
(459)\end{array}$ & E6RF86 & $\begin{array}{l}\text { Translation elongation } \\
\text { factor EF1- } \alpha\end{array}$ & R265 & 13 & 33 \\
\hline $\begin{array}{l}\text { CNBG_4027 } \\
(281)\end{array}$ & E6R6Y7 & $\begin{array}{l}\text { Ubiquinol-cytochrome-C } \\
\text { reductase iron-sulfur } \\
\text { subunit }\end{array}$ & CG01, CG03 & 8 & 33 \\
\hline $\begin{array}{l}\text { CNBG_3631 } \\
(138)\end{array}$ & E6R286 & Cofilin & CG03 & 4 & 33 \\
\hline $\begin{array}{l}\text { CNBG_5365 } \\
(431)\end{array}$ & E6R762 & Cellulase & CG02 & 12 & 32 \\
\hline $\begin{array}{l}\text { CNBG_5509 } \\
(213)\end{array}$ & E6QZ83 & $\begin{array}{l}\text { Conserved hypothetical } \\
\text { protein }\end{array}$ & R265 & 6 & 32 \\
\hline $\begin{array}{l}\text { CNBG_3378 } \\
(216)\end{array}$ & E6R3K5 & Elongation factor $1 \beta$ & $\begin{array}{l}\text { CG01, CG03, } \\
\text { R265 }\end{array}$ & 5 & 32 \\
\hline $\begin{array}{l}\text { CNBG_1866 } \\
(336)\end{array}$ & E6R7Z5 & $\begin{array}{l}\text { Glyceraldehyde-3- } \\
\text { phosphate dehydrogenase }\end{array}$ & CG03 & 9 & 31 \\
\hline $\begin{array}{l}\text { CNBG_4560 } \\
(225)\end{array}$ & E6R5Q4 & $\begin{array}{l}\text { Conserved hypothetical } \\
\text { protein }\end{array}$ & R265 & 6 & 31 \\
\hline $\begin{array}{l}\text { CNBG_6164 } \\
(187)\end{array}$ & E6REDO & $\begin{array}{l}\text { Conserved hypothetical } \\
\text { protein }\end{array}$ & CG01, CG03 & 5 & 31 \\
\hline $\begin{array}{l}\text { CNBG_3060 } \\
(228)\end{array}$ & E6RDF4 & GrpE protein & $\begin{array}{l}\text { CG01, CG02, } \\
\text { R265 }\end{array}$ & 6 & 30 \\
\hline $\begin{array}{l}\text { CNBG_4692 } \\
(191)\end{array}$ & E6R5B7 & $\begin{array}{l}\text { Nascent polypeptide- } \\
\text { associated complex } \\
\text { subunit- } \alpha\end{array}$ & CG03, R265 & 5 & 30 \\
\hline $\begin{array}{l}\text { CNBG_0959 } \\
(152)\end{array}$ & E6R4T7 & Cytoplasm protein & R265 & 4 & 30 \\
\hline $\begin{array}{l}\text { CNBG_1632 } \\
(547)\end{array}$ & E6R8N5 & ATP synthase $\beta$-subunit & CG02, R265 & 14 & 29 \\
\hline $\begin{array}{l}\text { CNBG_3753 } \\
(531)\end{array}$ & E6RDZ5 & Phosphoglycerate mutase & CG03 & 14 & 29 \\
\hline \multicolumn{6}{|c|}{ 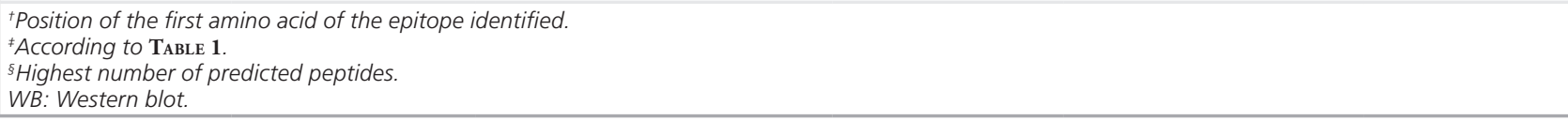 } \\
\hline
\end{tabular}


Table 2. Proteins and B-cell epitopes mapped by ABCPred and BCPreds algorithms identified by immunoblot sera from patients with cryptococcosis (cont.).

\begin{tabular}{|c|c|c|c|c|c|}
\hline Protein ID $\left(\mathrm{aa}^{+}\right)$ & Accession code & Name of protein & WB strain ${ }^{\ddagger}$ & Epitopes (n) & Epitopes $(\%)^{\S}$ \\
\hline $\begin{array}{l}\text { CNBG_1355 } \\
(432)\end{array}$ & E6QY25 & Endopeptidase & CG02 & 11 & 29 \\
\hline $\begin{array}{l}\text { CNBG_2617 } \\
\text { (199) }\end{array}$ & E6RAJ9 & $40 S$ ribosomal protein $\mathrm{S} 7$ & R265 & 5 & 29 \\
\hline $\begin{array}{l}\text { CNBG_5941 } \\
(158)\end{array}$ & E6RBX1 & Initiation factor $5 a$ & CG03, R265 & 4 & 29 \\
\hline $\begin{array}{l}\text { CNBG_0239 } \\
(614)\end{array}$ & E6ROK8 & Heat shock protein sks2 & R265 & 15 & 28 \\
\hline $\begin{array}{l}\text { CNBG_4851 } \\
(167)\end{array}$ & E6RFA3 & Cytoplasm protein & R265 & 4 & 28 \\
\hline $\begin{array}{l}\text { CNBG_1185 } \\
(418)\end{array}$ & E6QYKO & Succinyl-CoA ligase $\beta$-chain & $\begin{array}{l}\text { CG02, CG03, } \\
\text { R265 }\end{array}$ & 10 & 27 \\
\hline $\begin{array}{l}\text { CNBG_2079 } \\
(420)\end{array}$ & E6RA07 & $\begin{array}{l}\text { Mannitol-1-phosphate } \\
\text { dehydrogenase }\end{array}$ & CG02 & 10 & 27 \\
\hline $\begin{array}{l}\text { CNBG_0290 } \\
(251)\end{array}$ & E6ROCO & $\begin{array}{l}\text { Conserved hypothetical } \\
\text { protein }\end{array}$ & CG01 & 6 & 27 \\
\hline $\begin{array}{l}\text { CNBG_5765 } \\
(256)\end{array}$ & E6RCQ9 & 14-3-3 protein & R265 & 6 & 27 \\
\hline $\begin{array}{l}\text { CNBG_0379 } \\
(168)\end{array}$ & E6R058 & $\begin{array}{l}\text { Ubiquitin carboxyl-terminal } \\
\text { hydrolase }\end{array}$ & R265 & 4 & 27 \\
\hline $\begin{array}{l}\text { CNBG_4912 } \\
(756)\end{array}$ & E6RFH1 & Heat shock protein (Hsp70) & $\begin{array}{l}\text { CG01, CG02, } \\
\text { R265 }\end{array}$ & 17 & 26 \\
\hline $\begin{array}{l}\text { CNBG_2318 } \\
(175)\end{array}$ & E6R9A9 & Hypothetical protein & CG03 & 4 & 26 \\
\hline $\begin{array}{l}\text { CNBG_4789 } \\
(135)\end{array}$ & E6RF38 & $\begin{array}{l}\text { Conserved hypothetical } \\
\text { protein }\end{array}$ & CG02 & 3 & 26 \\
\hline $\begin{array}{l}\text { CNBG_0482 } \\
(408)\end{array}$ & E6QZV4 & Disulfide-isomerase & R265 & 9 & 25 \\
\hline $\begin{array}{l}\text { CNBG_4625 } \\
(407)\end{array}$ & E6R515 & $\begin{array}{l}\text { Pyruvate dehydrogenase e1 } \\
\text { component } \beta \text {-subunit }\end{array}$ & CG01 & 9 & 25 \\
\hline $\begin{array}{l}\text { CNBG_1460 } \\
(373)\end{array}$ & E6QXQ4 & $\begin{array}{l}\text { 3-isopropylmalate } \\
\text { dehydrogenase }\end{array}$ & CG03, R265 & 8 & 25 \\
\hline $\begin{array}{l}\text { CNBG_2499 } \\
(270)\end{array}$ & E6RA79 & Phosphomannomutase & CG03, R265 & 6 & 25 \\
\hline $\begin{array}{l}\text { CNBG_6043 } \\
(233)\end{array}$ & E6RCV4 & Glutathione transferase & CG01 & 5 & 25 \\
\hline $\begin{array}{l}\text { CNBG_0372 } \\
\text { (291) }\end{array}$ & E6R068 & $\begin{array}{l}\text { Conserved hypothetical } \\
\text { protein }\end{array}$ & CG03 & 6 & 24 \\
\hline $\begin{array}{l}\text { CNBG_1816 } \\
(401)\end{array}$ & E6R847 & Ketol-acid reductoisomerase & R265 & 8 & 23 \\
\hline $\begin{array}{l}\text { CNBG_5485 } \\
(152)\end{array}$ & E6QZ59 & Grx5-prov protein & CG03 & 3 & 23 \\
\hline $\begin{array}{l}\text { CNBG_0257 } \\
(221)\end{array}$ & E6R0I8 & $\begin{array}{l}\text { HHE domain-containing } \\
\text { protein }\end{array}$ & R265 & 4 & 21 \\
\hline $\begin{array}{l}\text { CNBG_0624 } \\
(125)\end{array}$ & E6R3U6 & $\begin{array}{l}\text { Conserved hypothetical } \\
\text { protein }\end{array}$ & CG02 & 2 & 18 \\
\hline \multicolumn{6}{|c|}{ 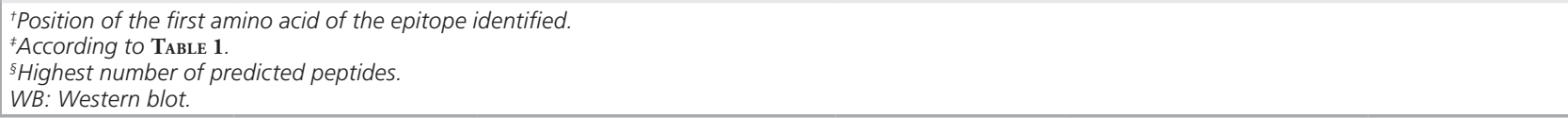 } \\
\hline
\end{tabular}


Table 2. Proteins and B-cell epitopes mapped by ABCPred and BCPreds algorithms identified by immunoblot sera from patients with cryptococcosis (cont.).

\begin{tabular}{|c|c|c|c|c|c|}
\hline Protein ID $\left(\mathrm{aa}^{\dagger}\right)$ & Accession code & Name of protein & WB strain ${ }^{\ddagger}$ & Epitopes (n) & Epitopes (\%) $)^{\S}$ \\
\hline $\begin{array}{l}\text { CNBG_2132 } \\
(197)\end{array}$ & E6R9V1 & Thioredoxin peroxidase tpx1 & $\begin{array}{l}\text { CG01, CG02, } \\
\text { R265 }\end{array}$ & 3 & 17 \\
\hline \multicolumn{6}{|c|}{$\begin{array}{l}{ }^{+} \text {Position of the first amino acid of the epitope identified. } \\
{ }^{*} \text { According to TABLE } 1 . \\
{ }^{5} \text { Highest number of predicted peptides. } \\
\text { WB: Western blot. }\end{array}$} \\
\hline
\end{tabular}

antigenicity in different strains, we believe that these proteins would be most promising for testing as antigens. However, after the analysis of the overlapping protein sequences in C. gattii (data not shown), we observed a high similarity (above 94\%) between proteins from C.gattii genotypes VGI and VGII, except for the enolase protein (51\%). Taken together, assessing the specificity of these antigens will be the next step to validate them for the diagnosis of cryptococcosis.

In addition, the fact that only six immunoreactive proteins were common to the three strains of C. gattii genotype VGII tested in our study is not surprising. For example, we recently demonstrated the significant genetic diversity of the C. gattii genotype VGII in Brazil using the multilocus sequence typing technique [57]. Of the six immunoreactive proteins identified here (TABLE 1), three are constitutive and involved in the cell cycle, cell division or the tricarboxylic acid cycle and were therefore excluded from this discussion.

Two of the three antigenic targets identified here, Hsp70 and GrpE, are members of the $70-\mathrm{kDa}$ heat shock protein family. Hsp70 was identified as an antigenic target in sera from cryptococcosis patients infected with the strains CG01, CG02 and R265. This finding corroborates previous studies that identified proteins of the Hsp family as potential biomarkers for cryptococcosis [58-60]. Hsp70 is a phylogenetically conserved chaperone protein whose expression increases in response to temperature variation and environmental stress [61]. The role of this protein as an antigenic target in the context of cryptococcosis has been reported by various studies in both humans (by Rodrigues et al. [62]) and animal models in the clinical and subclinical phases (by Jobbins et al. [56] and Young et al. [55]), thus supporting our findings.

To our knowledge, this is the first report of the involvement of the second type of protein in the chaperone family with a size of $70 \mathrm{kDa}(\mathrm{GrpE})$ as an antigenic target in the context of cryptococcosis. These new data have the potential to be used in the development of immunoassays because the same serum pool of neurocryptococcosis patients showed reactivity to GrpE in the three distinct strains of C. gattii genotype VGII.

The third protein identified in our study as an interesting antigenic target for the development of an immunoassay is the thiol peroxidase tpx 1. We identified this protein in the aforementioned CG01, CG02 and R265 C. gattii genotype VGII strains. It is interesting to note that thiol peroxidase, a protein that acts to remove peroxides, also acts in response to oxidative stress, similar to Hsp70. Such proteins have previously been identified as being essential for intracellular survival, virulence and resistance to oxidative and nitrosative stress in C. neoformans, as reported by Missall et al. [63-65] and Wang et al. [66]. The finding presented here that thiol peroxidase is an antigenic target in C. gattii genotype VGII corroborates the findings of Jobbins et al. [56] and supports the hypothesis that this protein is involved in the pathogenesis of $C$. gattiigenotype VGII infection in humans [62,67-69].

Other important proteins identified in the current study include the following: enolase and ATP synthase (found in strains CG01 and R265); phosphomannomutase (strains CG03 and R265); aconitase and Wos2 (strain CG02); and cofilin and CAN2 (strain CG03).

Enolase and ATP synthase appear to be important in the process of host invasion by the fungus. During the invasion of the brain and the CNS, penetration of the blood-brain barrier is a prerequisite for the establishment of meningoencephalitis by the opportunistic fungal pathogen $C$. neoformans. The fungal cells require a high level of energy to traverse this barrier, and enolase, which is an enzyme in the glycolysis pathway, could be essential for this purpose during the infection process [58]. In addition, the relative importance of plasminogen in infectious diseases is indicated by the surface-associated plasminogen-binding properties manifested by diverse species of human pathogens. Several 
proteins, including enolase, have been found to play a major role in the microbial recruitment of plasminogen [68].

Phosphomannomutase can be considered to be an indirect virulence factor for Cryptococcus spp. This statement is justified by the fact that this enzyme is responsible for the synthesis of mannose, which is a carbohydrate comprising up to two-thirds of the main cryptococcal virulence factor, the polysaccharide capsule. The capsular polysaccharide of $C$. neoformans helps to protect yeast against the host immune system due to its function as either an antiphagocytic factor and/or an antigenic polysaccharide that is extruded into tissue and fluids and produces an immunosuppressive effect. The capsular polysaccharide, GXM, comprises three major sugars: mannose, xylose and glucuronic acid. The identification of this protein as an antigenic target is not surprising because it is involved in the production of mannoprotein-mannose complexes that elicit a cytokine-mediated inflammatory immune response. Important factors for proliferation in host tissue include enzymes involved in central carbon metabolism (gluconeogenesis and acetylCoA synthesis), regulators of capsule and melanin synthesis and proteins involved in resistance to phagocytosis [17,70-72].

The identification of the proteins aconitase (an enzyme involved in the metabolism of carbohydrates) and Wos2 (a cochaperone of Hsp90) corroborates the results of a study by Crestani et al. [73], which showed that aconitase and Wos2 expression levels increase in C. gattii (strain R265) in response to a lack of iron in the culture medium. It is important to note that the common factors between our study and that of Crestani et al. [73] are the stress conditions to which $C$. gattii was exposed and that Wos 2 has been suggested to be an early marker of C. gattii infection in koalas [56]. Similar to enolase, the protein cofilin identified herein may play a relevant role in the process of the fungus spreading to the CNS. The rationale for this hypothesis is that cofilin interferes with the polymerization of F-actin and G-actin strands, thereby modulating the cytoskeleton of the target cell. This idea is in accordance with the results reported by Wang et al. [66], who demonstrated differential expression of cofilin in human umbilical vascular endothelial cells infected by $C$. neoformans.

The identification of CAN2 as an antigenic target in the context of cryptococcosis may be explained, at least in part, by this protein experiencing an increase in pressure in response to the change in the environmental $\mathrm{CO}_{2}$ tension $(0.033 \%)$ relative to that found in the host $(5 \%)$. This protein works as a sensor for this $\mathrm{CO}_{2}$ tension change and alerts the cell to the need for capsule thickening. This thickening is, in turn, an important virulence mechanism in cryptococcosis $[74,75]$.

Importantly, the applied B-cell epitope prediction was efficient because the majority of the proteins $(85.4 \%)$ presented a high percentage of epitopes. The high percentage of epitopes in nearly all of the identified proteins can be explained by the selection based on western blot analysis. It is important to highlight the fact that two proteins that were previously defined as hypothetical proteins showed a higher percentage ( $>42 \%)$ of epitopes. These hypothetical proteins exhibit a conserved homology in other species of Cryptococcus. The identified epitopes can be produced as synthetic peptides and could be tested for use in the diagnosis of cryptococcosis.

\section{Conclusion}

In conclusion, the applied combination of immunoproteomics and immunoinformatics methods was demonstrated to be a specific and powerful tool for identifying novel antigens from mycological pathogens. The major finding of this work was the identification of C. gattii proteins recognized as molecular targets by antibodies produced by patients with cryptococcal meningitis. In addition, we identified potential antigens that may be used for the development of more accurate serological diagnoses in human cryptococcal meningitis.

\section{Future perspective}

Cryptococcosis caused by C. gattii genotype VGII has resulted in significant repercussions over the years owing to the occurrence of outbreaks in Canada, mainly affecting immunocompetent individuals, causing high morbidity and mortality. Therefore, significant efforts have been devoted to the search for diagnostic tests that are sensitive, specific and can detect infection as early as possible. The immunogenic proteins and B-cell epitopes identified herein need to be investigated as antigens in serological tests to diagnose cryptococcal infection. These proteins could present cross-reaction with cryptococcal infection caused by other species. Although these proteins can react with multiple fungal species, some of these fungi may not be present in the patient. However, this is the first important step to selecting new target antigens to facilitate the immunodiagnosis of cryptococcosis. 


\section{Executive summary}

\section{Objectives of the study}

- The objective was to identify immunoreactive proteins using sera from patients with cryptococcosis.

- The study aimed to map B-cell epitopes from immunoreactive proteins from Cryptococcus gattii genotype VGII.

\section{Methods}

- 2D gel electrophoresis integrated with immunoblotting and mass spectrometry was used to identify immunoreactive proteins.

- $A B C$ Pred and BCPreds programs were utilized to predict epitopes for B cells.

\section{Conclusion}

- A total of 68 immunoreactive proteins were identified.

- The ABCPred and BCPreds programs generated 374 concordant peptides.

- The Hsp70, thioredoxin peroxidase and GrpE proteins were immunoreactive in at least three strains of C. gattii genotype VGII.

\section{Acknowledgements}

The authors would like to sincerely thank JFR Estanislau from the Unit of Protein Chemistry and Mass Spectrometry (MS-UniProt, Biotechnology Center, UFRGS, Brazil) for operating the mass spectrometer and J Batista de Oliveira Silva Jr for translation of the manuscript into English. The authors also thank $M$ do Amparo Salmito Cavalcanti for contributing to the acquisition of the clinical data for the subjects involved in the research and the patients in this study. The authors also thank the Renorbio Postgraduate Program for its research incentive in the northeastern region of Brazil.

\section{Financial \& competing interests} disclosure

This work was supported by the Laboratory of Immunogenetics and Molecular Biology (LIB), Federal University of Piaui, Brazil. The authors have no other relevant affiliations or financial involvement with any organization or entity with a financial interest in or financial conflict with the subject matter or materials discussed in the manuscript apart from those disclosed.

The revision of the English language of this manuscript was performed by American Journal Experts, funded by the Laboratory of Immunogenetics and Molecular Biology (LIB), Federal University of Piaui, Brazil.

\section{Ethical conduct of research}

The study protocol was approved by the State University of Piaui-Brazil Institutional Review Board (CEP 079/2008) and by the Brazilian National Ethics Committee (CONEP). All patients enrolled in the study signed forms providing free and informed consent.

\section{References}

Papers of special note have been highlighted as:

- of interest

- of considerable interest

1. Springer DJ, Chaturvedi V. Projecting global occurrence of Cryptococcus gattii. Emerg. Infect. Dis. 16(1), 14-20 (2010).

2. Del Poeta M, Casadevall A. Ten challenges on Cryptococcus and cryptococcosis. Mycopathologia 17(5-6), 303-310 (2012).

3. Chaturvedi V, Chaturvedi S. Cryptococcus gattii: a resurgent fungal pathogen. Trends Microbiol. 19(11), 564-571 (2011).

4. Harris J, Lockhart S, Chiller T. Cryptococcus gattii: where do we go from here? Med. Mycol. 50(2), 113-129 (2012).

5. Bartlett KH, Cheng PY, Duncan C et al. A decade of experience: Cryptococcus gattii in British Columbia. Mycopathologia 173(5-6), 311-319 (2012).

6. Trilles L, Meyer W, Wanke B, Guarro J, Lazera M. Correlation of antifungal susceptibility and molecular type within the Cryptococcus neoformans/C. gattii species complex. Med. Mycol. 50(3), 328-332 (2012).

7. Espinel-Ingroff A, Aller AI, Canton E et al. Cryptococcus neoformans-Cryptococcus gattii species complex: an international study of wild-type susceptibility endpoint distributions and epidemiological cutoff values for fluconazole, itraconazole, posaconazole, and voriconazole. Antimicrob. Agents Chemother. 56(11), 5898-5906 (2012).

8. Lockhart SR, Iqbal N, Cleveland AA et al. Species identification and antifungal susceptibility testing of Candida bloodstream isolates from population-based surveillance studies in two U.S. cities from 2008 to 2011. J. Clin. Microbiol. 50(11), 3435-3442 (2012).

9. Espinel-Ingroff A, Chowdhary A, CuencaEstrella M et al. Cryptococcus neoformansCryptococcus gattii species complex: an international study of wild-type susceptibility endpoint distributions and epidemiological cutoff values for amphotericin $\mathrm{B}$ and flucytosine. Antimicrob. Agents Chemother. 56(6), 3107-3113 (2012).

10. Thompson GR 3rd, Fothergill AW, Wiederhold NP, Vallor AC, Wickes BL, Patterson TF. Evaluation of Etest method for determining isavuconazole MICs against Cryptococcus gattii and Cryptococcus neoformans. Antimicrob. Agents Chemother. 52(8), 2959-2961 (2008).

11. Thompson GR 3rd, Wiederhold NP, Fothergill AW, Vallor AC, Wickes BL, Patterson TF. Antifungal susceptibilities among different serotypes of Cryptococcus gattii and Cryptococcus neoformans. Antimicrob. Agents Chemother. 53(1), 309-311 (2009).

12. Bovers M, Hagen F, Boekhout T. Diversity of the Cryptococcus neoformans-Cryptococcus gattii species complex. Rev. Iberoam. Micol. 25(1), S4-S12 (2008).

13. Leal AL, Faganello J, Bassanesi MC, Vainstein MH. Cryptococcus species identification by multiplex PCR. Med. Mycol. 46(4), 377-383 (2008).

14. Posteraro B, Vella A, Cogliati M et al. Matrixassisted laser desorption ionization-time of flight mass spectrometry-based method for discrimination between molecular types of Cryptococcus neoformans and Cryptococcus gattii. J. Clin. Microbiol. 50(7), 2472-2476 (2012).

15. Firacative C, Trilles L, Meyer W. MALDITOF MS enables the rapid identification of the major molecular types within the Cryptococcus neoformans/ C. gattii species complex. PLoS ONE 7(5), e37566 (2012).

16. McTaggart LR, Lei E, Richardson SE, Hoang L, Fothergill A, Zhang SX. Rapid identification of Cryptococcus neoformans and Cryptococcus gattii by matrix-assisted laser desorption ionization-time of flight mass spectrometry. J. Clin. Microbiol. 49(8), 3050-3053 (2011). 
17. Kronstad JW, Attarian R, Cadieux B et al. Expanding fungal pathogenesis: Cryptococcus breaks out of the opportunistic box. Nat. Rev. Microbiol. 9(3), 193-203 (2011).

18. D'Souza CA, Kronstad JW, Taylor G et al. Genome variation in Cryptococcus gattii, an emerging pathogen of immunocompetent hosts. MBio 2(1), e00342-10 (2011).

- Excellent article for understanding the pathogenesis of cryptococcosis.

19. Byrnes EJ 3rd, Li W, Lewit Y et al. First reported case of Cryptococcus gattii in the southeastern USA: implications for travelassociated acquisition of an emerging pathogen. PLoS ONE 4(6), e5851 (2009).

20. Kidd SE, Hagen F, Tscharke RL et al. A rare genotype of Cryptococcus gattii caused the cryptococcosis outbreak on Vancouver Island (British Columbia, Canada). Proc. Natl Acad. Sci. USA 101(49), 17258-17263 (2004).

21. MacDougall L, Fyfe M, Romney M, Starr M, Galanis E. Risk factors for Cryptococcus gattii infection, British Columbia, Canada. Emerg. Infect. Dis. 17(2), 193-199 (2011).

22. Chowdhary A, Randhawa HS, Boekhout T, Hagen F, Klaassen CH, Meis JF. Temperate climate niche for Cryptococcus gattii in northern Europe. Emerg. Infect. Dis. 18(1), 172-174 (2012).

23. Hagen F, Colom MF, Swinne D et al. Autochthonous and dormant Cryptococcus gattii infections in Europe. Emerg. Infect. Dis. 18(10), 1618-1624 (2012).

24. Colom MF, Hagen F, Gonzalez A et al. Ceratonia siliqua (carob) trees as natural habitat and source of infection by Cryptococcus gattii in the Mediterranean environment. Med. Mycol. 50(1), 67-73 (2012).

25. Darze C, Lucena R, Gomes I, Melo A. The clinical laboratory characteristics of 104 cases of cryptococcal meningoencephalitis. Rev. Soc. Bras. Med. Trop. 33(1), 21-26 (2000).

26. Martins LM, Wanke B, Lazera Mdos S et al. Genotypes of Cryptococcus neoformans and Cryptococcus gattii as agents of endemic cryptococcosis in Teresina, Piaui (northeastern Brazil). Mem. Inst. Oswaldo Cruz 106(6), 725-730 (2011).

- Characterization of cryptococcosis as an important fungal disease in immunocompetent children and young adults in northeastern Brazil caused by Cryptococcus gattii genotype VGII.

27. Nishikawa MM, Lazera MS, Barbosa GG et al. Serotyping of 467 Cryptococcus neoformans isolates from clinical and environmental sources in Brazil: analysis of host and regional patterns. J. Clin. Microbiol. 41(1), 73-77 (2003).

28. Santos WR, Meyer W, Wanke B et al. Primary endemic Cryptococcosis gattii by molecular type VGII in the state of Para, Brazil. Mem. Inst. Oswaldo Cruz 103(8), 813-818 (2008).

29. Severo CB, Xavier MO, Gazzoni AF, Severo LC. Cryptococcosis in children. Paediatr. Respir. Rev. 10(4), 166-171 (2009).

30. Galanis E, MacDougall L. Epidemiology of Cryptococcus gattii, British Columbia, Canada, 1999-2007. Emerg. Infect. Dis. 16(2), 251-257 (2010).

31. Lindsley MD, Mekha N, Baggett HC et al. Evaluation of a newly developed lateral flow immunoassay for the diagnosis of cryptococcosis. Clin. Infect. Dis. 53(4), 321-325 (2011).

32. McMullan BJ, Halliday C, Sorrell TC et al. Clinical utility of the cryptococcal antigen lateral flow assay in a diagnostic mycology laboratory. PLoS ONE 7(11), e49541 (2012).

33. Hansen J, Slechta ES, Gates-Hollingsworth MA et al. Large-scale evaluation of the immuno-mycologics lateral flow and enzymelinked immunoassays for detection of cryptococcal antigen in serum and cerebrospinal fluid. Clin. Vaccine Immunol. 20(1), 52-55 (2012).

34. Meyer W, Castaneda A, Jackson S, Huynh M, Castaneda E. Molecular typing of IberoAmerican Cryptococcus neoformans isolates. Emerg. Infect. Dis. 9(2), 189-195 (2003).

35. Bradford MM. A rapid and sensitive method for the quantitation of microgram quantities of protein utilizing the principle of proteindye binding. Anal. Biochem. 72, 248-254 (1976).

36. Laemmli UK. Cleavage of structural proteins during the assembly of the head of bacteriophage T4. Nature 227(5259), 680-685 (1970).

37. Neuhoff V, Arold N, Taube D, Ehrhardt W. Improved staining of proteins in polyacrylamide gels including isoelectric focusing gels with clear background at nanogram sensitivity using Coomassie Brilliant Blue G-250 and R-250. Electrophoresis 9(6), 255-262 (1988).

38. Saha S, Raghava GP. Prediction of continuous $\mathrm{B}$-cell epitopes in an antigen using recurrent neural network. Proteins 65(1), 40-48 (2006).

39. El-Manzalawy Y, Dobbs D, Honavar V. Predicting linear B-cell epitopes using string kernels. J. Mol. Recognit. 21(4), 243-255 (2008).

40. Faria AR, Costa MM, Giusta MS et al. Highthroughput analysis of synthetic peptides for the immunodiagnosis of canine visceral leishmaniasis. PLoS Negl. Trop. Dis 5(9), e1310 (2011).

41. Costa MM, Andrade HM, Bartholomeu DC et al. Analysis of Leishmania chagasi by 2-D difference gel electrophoresis (2-D DIGE) and immunoproteomic: identification of novel candidate antigens for diagnostic tests and vaccine. J. Proteome Res. 10(5), 2172-2184 (2011).

- Illustrates the proteomic and in silico analysis used to identify novel proteins and peptides for diagnostic tests.

42. Pedersen SK, Sloane AJ, Prasad SS et al. An immunoproteomic approach for identification of clinical biomarkers for monitoring disease: application to cystic fibrosis. Mol. Cell Proteomics 4(8), 1052-1060 (2005).

43. Zhu YZ, Cai CS, Zhang W et al. Immunoproteomic analysis of human serological antibody responses to vaccination with whole-cell pertussis vaccine (WCV). PLoS ONE 5(11), e13915 (2010).

44. Tjalsma H, Schaeps RM, Swinkels DW. Immunoproteomics: from biomarker discovery to diagnostic applications. Proteomics Clin. Appl. 2(2), 167-180 (2008).

45. Hess JL, Blazer L, Romer T, Faber L, Buller RM, Boyle MD. Immunoproteomics. J. Chromatogr. B Analyt. Technol. Biomed. Life Sci. 815 (1-2), 65-75 (2005).

46. Santi L, Silva WO, Pinto AF, Schrank A, Vainstein MH. Metarhizium anisopliae host-pathogen interaction: differential immunoproteomics reveals proteins involved in the infection process of arthropods. Fungal Biol. 114(4), 312-319 (2010).

47. Liao Y, Deng J, Zhang A et al. Immunoproteomic analysis of outer membrane proteins and extracellular proteins of Actinobacillus pleuropneumoniae JL03 serotype 3. BMC Microbiol. 9, 172 (2009).

48. Yang Y, Wang L, Yin J et al. Immunoproteomic analysis of Brucella melitensis and identification of a new immunogenic candidate protein for the development of brucellosis subunit vaccine. Mol. Immunol. 49(1-2), 175-184 (2011).

49. Wu Z, Zhang W, Lu C. Immunoproteomic assay of surface proteins of Streptococcus suis serotype 9. FEMS Immunol. Med. Microbiol. 53(1), 52-59 (2008).

50. Saisongkorh W, Kowalczewska M, Azza S, Decloquement P, Rolain JM, Raoult D. Identification of candidate proteins for the diagnosis of Bartonella henselae infections using an immunoproteomic approach. FEMS Microbiol. Lett. 310(2), 158-167 (2010).

51. Lopez JE, Porcella SF, Schrumpf ME et al. Identification of conserved antigens for early 
serodiagnosis of relapsing fever Borrelia. Microbiology 155(Pt 8), 2641-2651 (2009).

52. Altindis E, Tefon BE, Yildirim V et al. Immunoproteomic analysis of Bordetella pertussis and identification of new immunogenic proteins. Vaccine 27(4), 542-548 (2009).

53. Bunk S, Susnea I, Rupp J et al. Immunoproteomic identification and serological responses to novel Chlamydia pneumoniae antigens that are associated with persistent $C$. pneumoniae infections. J. Immunol. 180(8), 5490-5498 (2008).

54. Al Dahouk S, Nockler K, Scholz HC, Tomaso H, Bogumil R, Neubauer H. Immunoproteomic characterization of Brucella abortus 1119-3 preparations used for the serodiagnosis of Brucella infections. J. Immunol. Methods 309(1-2), 34-47 (2006).

55. Young M, Macias S, Thomas D, Wormley FL Jr. A proteomic-based approach for the identification of immunodominant Cryptococcus neoformans proteins. Proteomics 9(9), 2578-2588 (2009).

-. Protein identification involved in the pathogenesis of cryptococcosis.

56. Jobbins SE, Hill CJ, D'Souza-Basseal JM, Padula MP, Herbert BR, Krockenberger MB. Immunoproteomic approach to elucidating the pathogenesis of cryptococcosis caused by Cryptococcus gattii. J. Proteome Res. 9(8), 3832-3841 (2010).

-. Immunoproteomic approach for the identification of Cryptococcus gattii immunoreactive proteins in an animal model.

57. Trilles L, Souto AC, Barbosa GG et al. Multilocus sequence typing reveals a high genetic diversity among the Brazilian VGII population. Presented at: 8th International Conference on Cryptococcus and Cryptococcosis. Charleston, SC, USA, 1-5 May 2011.

58. Kakeya H, Udono H, Maesaki S et al. Heat shock protein 70 (Hsp70) as a major target of the antibody response in patients with pulmonary cryptococcosis. Clin. Exp. Immunol. 115(3), 485-490 (1999).

59. Kakeya $\mathrm{H}$, Udono $\mathrm{H}$, Ikuno $\mathrm{N}$ et al. A 77-kilodalton protein of Cryptococcus neoformans, a member of the heat shock protein 70 family, is a major antigen detected in the sera of mice with pulmonary cryptococcosis. Infect. Immun. 65(5), 1653-1658 (1997).

60. Steen BR, Zuyderduyn S, Toffaletti DL et al. Cryptococcus neoformans gene expression during experimental cryptococcal meningitis. Eukaryot. Cell 2(6), 1336-1349 (2003).

61. Mayer MP, Bukau B. Hsp70 chaperones: cellular functions and molecular mechanism. Cell. Mol. Life Sci. 62(6), 670-684 (2005).

62. Rodrigues ML, Nakayasu ES, Oliveira DL et al. Extracellular vesicles produced by Cryptococcus neoformans contain protein components associated with virulence. Eukaryot. Cell7(1), 58-67 (2008).

- Identifies proteins associated with the virulence of Cryptococcus neoformans.

63. Missall TA, Pusateri ME, Lodge JK. Thiol peroxidase is critical for virulence and resistance to nitric oxide and peroxide in the fungal pathogen, Cryptococcus neoformans. Mol. Microbiol. 51(5), 1447-1458 (2004).

64. Missall TA, Moran JM, Corbett JA, Lodge JK. Distinct stress responses of two functional laccases in Cryptococcus neoformans are revealed in the absence of the thiol-specific antioxidant Tsa1. Eukaryot. Cell 4(1), 202-208 (2005).

65. Missall TA, Pusateri ME, Donlin MJ, Chambers KT, Corbett JA, Lodge JK. Posttranslational, translational, and transcriptional responses to nitric oxide stress in Cryptococcus neoformans: implications for virulence. Eukaryot. Cell 5(3), 518-529 (2006).

66. Wang XJ, Zhu YJ, Cui JG et al. Proteomic analysis of human umbilical vein endothelial cells incubated with Cryptococcus neoformans var. neoformans. Mycoses 54(5), e336-e343 (2011).

67. Rodrigues ML, Nimrichter L, Oliveira DL, Nosanchuk JD, Casadevall A. Vesicular transcell wall transport in fungi: a mechanism for the delivery of virulence-associated macromolecules? Lipid Insights 2, 27-40 (2008).

68. Nosanchuk JD, Nimrichter L, Casadevall A, Rodrigues ML. A role for vesicular transport of macromolecules across cell walls in fungal pathogenesis. Commun. Integr. Biol. 1(1), 37-39 (2008).

69. Biondo C, Mancuso G, Midiri A et al. Identification of major proteins secreted by
Cryptococcus neoformans. FEMS Yeast Res. 6(4), 645-651 (2006).

70. De Jesus M, Chow SK, Cordero RJ, Frases S, Casadevall A. Galactoxylomannans from Cryptococcus neoformans varieties neoformans and grubii are structurally and antigenically variable. Eukaryot. Cell9(7), 1018-1028 (2010).

71. Cottrell TR, Griffith CL, Liu H, Nenninger AA, Doering TL. The pathogenic fungus Cryptococcus neoformans expresses two functional GDP-mannose transporters with distinct expression patterns and roles in capsule synthesis. Eukaryot. Cell 6(5), 776-785 (2007).

72. Zaragoza O, Rodrigues ML, De Jesus M, Frases S, Dadachova E, Casadevall A. The capsule of the fungal pathogen Cryptococcus neoformans. Adv. Appl. Microbiol. 68, 133-216 (2009).

73. Crestani J, Carvalho PC, Han X et al. Proteomic profiling of the influence of iron availability on Cryptococcus gattii. J. Proteome Res. 11(1), 189-205 (2011).

74. Mogensen EG, Janbon G, Chaloupka J et al. Cryptococcus neoformans senses $\mathrm{CO}_{2}$ through the carbonic anhydrase CAN2 and the adenylyl cyclase CAC1. Eukaryot. Cell 5(1), 103-111 (2006).

75. Kozubowski L, Lee SC, Heitman J. Signalling pathways in the pathogenesis of Cryptococcus. Cell Microbiol. 11(3), 370-380 (2009).

\section{Websites}

101. Matrix Science. Mascot software. www.matrixscience.com

102. Broad Institute Protein Database. www.broadinstitute.org/annotation/genome/ cryptococcus_neoformans_b/MultiHome. html

103. Blast2GO. Software for Biologists. www.blast2go.org

104. National Center for Biotechnology Information (NCBI) BLAST database. http://blast.ncbi.nlm.nih.gov/Blast.cgi

105. ABCPred. Artificial neural network-based B-cell epitope prediction server. www.imtech.res.in/raghava/abcpred

106. Iowa State University. Department of Computer Science. Artificial Intelligence Research Laboratory. BCPreds. http://ailab.cs.iastate.edu/bcpreds 